\title{
Optimasi Produksi Crude Palm Oil (cpo) Dan Inti Sawit (Kernel) Studi Kasus PT.
} Mega Sawindo Perkasa

\author{
Andar D Marpaung ${ }^{1}$, Widuri Susilawati ${ }^{2}$, Asnawati Is ${ }^{2}$ \\ ${ }^{1}$ Alumni Program Studi Agribisnis Fakultas Pertanian UMB \\ ${ }^{2}$ Program Studi Agribisnis Fakultas Pertanian UMB \\ widurisusilawati@yahoo.co.id, zahira_siregar@yahoo.co.id
}

\begin{abstract}
ABSTRAK
Penelitian dilakukan di PT. Mega Sawindo Perkasa Kecamatan Pelepat Kabupaten Bungo dengan pertimbangan bahwa PT. Mega Sawindo Perkasa merupakan suatu unit usaha yang mengolah Tandan Buah Segar (TBS) menjadi Crude Palm Oil (CPO) dan Inti Sawit (Kernel) dan memiliki Pabrik Pengolahan Kelapa Sawit (PPKS) yang memiliki kapasitas 80 ton/jam. Penelitian dilakukan pada 05 Februari 2017 hingga 05 April 2017 dengan tujuan untuk menganalisis optimasi produksi (CPO) dan Inti Sawit (Kernel) pada PT. Mega Sawindo Perkasa dan menganalisis produksi CPO dan Kernel pada PT. Mega Sawindo Perkasa apabila faktor produksi yang ada mengalami perubahan.

Metode penelitian yang digunakan adalah metode studi kasus dengan lokasi PT. Mega Sawindo Perkasa. Metode pengolahan data yang digunakan adalah tabulasi dan komputasi. Data dianalisis dalam model perencanaan program linier dengan menggunakan software Linear Interactive and Discrete Optimizer (LINDO).

Hasil penelitian menunjukkan bahwa aktivitas produksi CPO dan Kernel pada PT. Mega Sawindo perkasa tahun 2016 belum mencapai kondisi Optimal dapat dilihat dari keuntungan optimal dan aktual yang memiliki selisih Rp. 29.059.887.884,96 yang berarti keuntungan perusahaan dapat ditingkatkan sebesar 40,71 \% dari keuntungan yang diperoleh perusahaan. Ketersediaan tenaga kerja langsung merupakan sumberdaya pembatas untuk mengoptimalkan keuntungan perusahaan sedangkan sumberdaya ketersediaan TBS pembelian dari pihak swasta, kuota pembelian, trasnsfer TBS menjadi CPO dan transfer TBS menjadi Kernel/Kernel mengalami kelebihan.
\end{abstract}

\section{Kata kunci : Crude Palm Oil (CPO), Inti Sawit, Optimasi Produksi}

\section{PENDAHULUAN}

Salah satu sub sektor yang cukup besar potensi adalah sub sektor perkebunan. Meskipun kontribusi sub sektor perkebunan terhadap pembentukan PDB belum terlalu besar yaitu 2,11 persen pada tahun 2015 atau merupakan urutan ketiga di sektor pertanian setelah sub sektor tanaman pangan dan perikanan, akan tetapi sub sektor ini merupakan penyedia bahan baku untuk sektor industri, penyerap tenaga kerja dan penghasil devisa (BPS, 2015). Beberapa komoditas perkebunan yang ada di Indonesia antara lain kelapa, karet, kelapa sawit, tebu, lada, kopi, tembakau dan kakao.
Salah satu komoditas hasil perkebunan yang mempunyai peran yang cukup penting dalam kegiatan perekonomian di Indonesia adalah kelapa sawit. Kelapa sawit juga salah satu komoditas ekspor Indonesia yang cukup penting sebagai penghasil devisa negara sesudah minyak dan gula. Indonesia merupakan negara produsen dan eksportir kelapa sawit terbesar dunia (BPS, 2015). Pada masa depan, minyak sawit diyakini tidak hanya mampu menghasilkan berbagai hasil industri hilir yang dibutuhkan manusia seperti minyak goreng, mentega, sabun, kosmetika, dan lain-lain, tetapi juga dapat menjadi subtitusi bahan bakar minyak yang saat ini sebagian besar dipenuhi dengan 
minyak bumi (Setyamidjaja, 2006).

Peluang untuk pengembangan agribisnis kelapa sawit masih cukup terbuka bagi Indonesia, terutama karena ketersediaan sumberdaya alam/lahan, tenaga kerja, teknologi maupun tenaga ahli. Indonesia mendominasi pemenuhan permintaan kelapa sawit dunia yang semakin meningkat sebesar 5 persen pertahunnya. Indonesia memproduksi sekitar 43 persen dari total produksi minyak kelapa sawit mentah $\mathrm{CPO}$ didunia. Kegiatan ekonomi kelapa sawit memberi kontribusi besar terhadap perekonomian Indonesia yang terus dikembangkan.

Luas areal dan produksi perkebunan di Provinsi Jambi adalah \pm 736.514 Ha, dengan demikian ada banyak Perusahaan yang bergerak dibidang kelapa sawit. Diantaranya PT. Mega Sawindo Perkasa yang berlokasi di kecamatan Pelepat Kabupaten Bungo. PT. Mega Sawindo Perkasa merupakan unit usaha yang memiliki areal seluas \pm 5.263.289 Ha. Areal kelapa sawit terbesar diwilayah Jambi. Selain itu PT. Mega Sawindo Perkasa merupakan unit usaha yang memiliki Produktivitas yang cukup tinggi. Jumlah yang tinggi menunjukkan banyaknya produksi Tandan Buah Segar (TBS) dari kebun TM (Tanaman Menghasilkan) milik PT. Mega Sawindo Perkasa yang merupakan bahan baku utama dalam memproduksi Crude Palm Oil (CPO) dan Inti Sawit (Kernel) pada PPKS.

PT. Mega Sawindo Perkasa memiliki satu unit Pabrik Pengolahan Kelapa Sawit (PPKS) dengan kapasitas 80 ton per jam dan beroperasi selama 10 jam per hari. Produk yang dihasilkan PPKS adalah CrudePalm Oil (CPO) dan inti sawit (Kernel), serta hasil sampingan berupa serabut (sebagai bahan bakar boiler), tandan kosong, cangkang, arang abu boiler, dan solid. PT. Mega
Sawindo Perkasa memperoleh bahan baku kelapa sawit dari hasil panen kebun milik perusahaan sendiri dan dari petani kemitraan.

PT. Mega Sawindo Perkasa menemui kendala dalam kegiatan produksinya, bahwa produksi hanya mencapai rata-rata 500.000 $\mathrm{Kg} /$ hari, berbeda dengan keadaan sebenarnya bahwa kapasitas pabrik yang terpasang mencapai 80 ton/jam yang artinya kapasitas pabrik mencapai $800.000 \mathrm{Kg} /$ hari. Ketersediaan kelapa sawit sangat mempengaruhi jumlah produksi pabrik. Kendala yang dihadapi perusahaan yang meliputi jumlah dan ketersediaan bahan baku yang terbatas, penggunaan kapasitas terpasang dipabrik yang belum efisien serta penggunaan tenaga kerja baik di kebun maupun di pabrik. Kendala-kendala ini mengakibatkan tujuan untuk memaksimumkan keuntungan belum dapat tercapai. Oleh karena itu penelitian mengenai optimasi produksi Crude Palm Oil (CPO) dan Inti Sawit (Kernel) perlu dilakukan. Adapun tujuan dari penelitian adalah untuk mengetahui produksi Crude Palm Oil (CPO) dan Inti Sawit (Kernel) pada PT. Mega Sawindo Perkasa apakah sudah optimal dilihat dari keuntungan dan menganalisis produksi Crude Palm Oil (CPO) dan Inti Sawit (Kernel) pada PT. Mega Sawindo Perkasa apabila faktor produksi yang ada mengalami perubahan.

\section{METODOLOGI PENELITIAN}

\section{Tempat dan Waktu Penelitian}

Pemilihan lokasi dilakukan secara sengaja (purposive) yaitu di PT. Mega Sawindo Perkasa Kecamatan Pelepat Kabupaten Bungo. Lokasi dipilih dengan pertimbangan bahwa PT. Mega Sawindo Perkasa merupakan suatu unit usaha yang mengolah TBS menjadi CPO dan Kernel. Selain itu juga PT. Mega Sawindo Perkasa 
memiliki Pabrik Pengolahan Kelapa Sawit (PPKS) yang memiliki kapasitas 80 ton/jam.

\section{Jenis dan Sumber Data}

Jenis data yang digunakan dalam penelitian ini adalah data primer dan data sekunder. Data primer diperoleh melalui teknik wawancara dengan staf dan karyawan PT. Mega Sawindo Perkasa bagian produksi dan pengamatan langsung. Data sekunder diperoleh dari instansi terkait yaitu Badan Pusat Statistik, Dinas Perkebunan Provinsi Jambi, PT. Mega Sawindo Perkasa dan literatur-literatur yang terkait dengan penelitian. Data sekunder dari PT. Mega Sawindo Perkasa yang diperlukan adalah data bulanan dari bulan Januari sampai dengan Desember tahun 2016.

\section{Metode Penelitian}

Metode penelitian yang digunakan adalah metode studi kasus dengan lokasi PT. Mega Sawindo Perkasa. Metode studi kasus adalah penelitian terhadap suatu kasus secara intensif dan mendalam terhadap objek tertentu. Sampel dalam penelitian ini adalah pekerja pada perkebunan dan pengolahan.

Metode pengambilan data dalam penelitian ini menggunakan teknik pengumpulan data dengan studi pustaka (Liberary Research) dan studi lapangan (Field Research)

\section{Metode Analisis Data}

Pengolahan data dilakukan dengan menggunakan metode tabulasi dan komputasi. Pengolahan data dimulai dengan mentabulasi data yang telah dikumpulkan kemudian dilakukan pengolahan dan analisis data dengan menyusun daftar variabel yang dimasukkan dalam tabel. Kondisi biaya produksi akan dianalisis secara deskriptif berdasarkan tabulasi data.

Untuk analisis optimasi produksi disusun berdasarkan aktivitas dalam lajur kendala serta fungsi tujuan yang ingin dicapai ke dalam suatu model pemprograman linier. Data yang diperoleh dan telah ditabulasikan secara manual diolah dengan komputer menggunakan software Linear Interactive and Discrete Optimizer (LINDO). LINDO digunakan sebagai media olah data karena memiliki kelebihan berupa mudah dan sederhana dalam mengoperasikannya, hasil olahnya mudah dibaca dan memberikan hasil analisis sensitivitas yang baik untuk parameter fungsi tujuan maupun fungsi kendala. Sesuai dengan tujuan, maka fungsi tujuan dan fungsi kendala untuk model program linier dirumuskan sebagai berikut.

\section{Fungsi Tujuan :}

Memaksimumkan :

$z=\sum_{j=1}^{n} x 1 j+\sum_{j=1}^{n} x 2 j-\sum_{j=1}^{n} x 3 j-\sum_{j=1}^{n} x 4 j-\sum_{j=1}^{n} x 5 j$

\section{Keterangan :}

Z : Keuntungan total yang ingin dicapai oleh perusahaan per bulan, diukur dalam satuan Rupiah (Rp).

X1j : Biaya TBS dari kebun sendiri per bulan $(\mathrm{Rp} / \mathrm{Kg}, \mathrm{J}=1,2,3, \ldots 12)$

$\mathrm{X} 2 \mathrm{j}$ : Biaya pembelian TBS dari luar kebun $(\mathrm{Rp} / \mathrm{Kg}, \mathrm{J}=1,2,3, \ldots 12$

$\mathrm{X} 3 \mathrm{j}$ : Harga jual CPO per bulan $(\mathrm{Kg}, \mathrm{J}=$ $1,2,3, \ldots 12)$

X4j : Harga jual Kernel/Kernelperbulan $(\mathrm{Kg}, \mathrm{J}=1,2,3, \ldots 12)$

X5j : Biaya pengolahan TBS menjadi CPO dan Kernel di pabrik per bulan $(\mathrm{Kg}, \mathrm{J}=1,2,3, \ldots 12)$

\section{Fungsi Kendala}




\section{Koefisien Fungsi Kendala}

$\mathrm{a}_{1 \mathrm{j}} \quad$ : Kendala kapasitas maksimal pabrik di pabrik per bulan.

$a_{2 j} \quad$ : Kendala keterbatasan ketersediaan pembelian

$a_{3 j} \quad$ : Kendala kuota pembelian

$a_{4 j} \quad$ Kendala ketersediaan tenaga kerja langsung

$a_{5 j} \quad$ : Kendala transfer (rendemen) CPO

$\mathrm{a}_{6 \mathrm{j}}$ : Kendala transfer (rendemen) Kernel/Kernel

Penentuan nilai Right Hand Side (RHS) Fungsi Kendala

$\mathrm{b}_{1 \mathrm{j}} \quad$ : kapasitas pabrik yang terpasang (80 ton/jam $=80.000 \mathrm{Kg} / \mathrm{Jam})$ dengan waktu pengolahan (10 jam) dalam satu hari dalam 1 bulan produksi $(25$ hari kerja) $(\mathrm{J}=1,2,3, \ldots 12)$.

$\mathrm{b}_{2 \mathrm{j}}$ : kendala keterbatasan pembelian TBS dengan pembatasan pemasokan daripihak ke-3 (swasta) sebesar 55 persen

$\mathrm{b}_{3 \mathrm{j}} \quad$ : Jumlah tenaga kerja pengolahan yang tersedia per bulan di pabrik dalam satuan HOK. Jumlah HOK tersebut diperhitungkan berdasarkan hari olah per bulan $\mathrm{j}$ dengan 10 jam kerja per hari olah $(\mathrm{J}=1,2,3, \ldots 12)$.

$\mathrm{b}_{3 \mathrm{j}} \quad$ : Jumlah CPO maksimum yang dapat dihasilkan oleh pabrik per bulan, dalam satuan Kg. Jumlah CPO maksimum dihitung berdasarkan kapasitas terpasang pabrik dalam satuan $\mathrm{Kg}$ TBS/jam dikalikan jumlah jam olah per bulan dikalikan rendemen $\mathrm{CPO}$ di pabrik $(\mathrm{J}=$ $1,2,3, \ldots .12)$

$\mathrm{b}_{4 \mathrm{j}} \quad$ : Jumlah produksi TBS yang dapat dihasilkan oleh kebun sendiri dan kebun kemitraan untuk diolah per bulan, dlam satuan $\mathrm{Kg}$ dengan asumsi produksi TBS dapat ditingkatkan
$(\mathrm{J}=1,2,3, \ldots 12)$

Hasil yang diperoleh dari analisis data menggunakan LINDO adalah berupa analisis primal, dual, dan sensitivitas. Analisis primal akan memberikan informasi mengenai kombinasi faktor produksi mana saja yang termasuk dalam skema optimal, serta besarnya kuantitas dari kombinasi faktor produksi yang masuk dalam skema optimal dan yang tidak masuk dalam skema optimal. Dengan analisis primal dapat mengetahui jumlah kombinasi $\left(\mathrm{X}_{\mathrm{ijk}}\right)$ yang terbaik untuk menghasilkan tujuan $\mathrm{Z}$, dengan kendala keterbatasan sumberdaya yang tersedia $\left(b_{\mathrm{jk}}\right)$. Analisis slack dan dual akan memberikan penilaian terhadap sumber daya yang digunakan dalam model. Nilai slack dan dual yang dihasilkan berdasarkan olahan LINDO menunjukkan perubahan dalam fungsi tujuan apabila sumberdaya tersebut berubah satu satuan. Nilai yang dihasilkan dual dalam analisis dual menunjukkan perubahan dalam fungsi tujuan apabila sumber daya tersebut berubah satu satuan. Penilaian ini dilakukan dengan melihat nilai slack / surplus dan nilai dual yang ada. Apabila nilai slack or surplus lebih besar dari nol dan nilai dual sama dengan nol maka dapatdisimpulkan sumberdaya tersebut berlebih (surplus).

Sumberdaya dengan nilai dual sama dengan nol disebut sebagai kendala pasif, karena tidak akan mengubah fungsi tujuan jika terjadi perubahan sebesar satu satuan. Sebaliknya apabila nilai slack or surplus sama dengan nol dan nilai dual lebih besar dari nol, maka dapat disimpulkan bahwa sumberdaya tersebut merupakan sumberdaya yang digunakan tersebut langka yang berarti menjadi pembatas bagi fungsi tujuan. Sumberdaya dengan nilai dual lebih besar dari nol disebut sebagai kendala aktif yang menjadi pembatas dalam kegiatan produksi 


\section{b. Analisis Sensitivitas}

Analisis sensitivitas digunakan untuk menjawab tujuan penelitian yaitu menganalisis kondisi produksi CPO dan Kernel pada PT. Mega Sawindo Perkasa apabila faktor produksi yang ada mengalami perubahan. Analisis sensitivitas dilakukan untuk mengetahui perubahan parameter yang terjadi terhadap program linear. Melalui analisis ini dapat dilihat seberapa besar perubahan (kenaikan atau penurunan) harga atau biaya faktor produksi yang masih diperbolehkan agar tidak merubah skema optimal dan seberapa besar perubahan (kenaikan atau penurunan) kuantitas sumber daya yang diperoleh sehingga hasil optimal tidak mengalami perubahan.

\section{HASIL DAN PEMBAHASAN}

Optimasi Produksi Crude Palm Oil (CPO) dan Inti Sawit (Kernel) pada PT. Mega Sawindo Perkasa

Analisis optimalisasi produksi CPO dan Kernel dilakukan dengan tujuan memaksimumkan keuntungan yang diterima oleh Pabrik Kelapa Sawit PT. Mega Sawindo Perkasa dengan melakukan penjualan dua jenis produk yaitu CPO dan Kernel selama periode satu tahun (2016). Optimalisasi didasarkan pada metode penelitian yang didahului dengan penentuan fungsi tujuan dilanjutkan dengan penentuan fungsi kendala.

\section{Penentuan Fungsi Tujuan}

Bahan baku yang digunakan oleh PT. Mega Sawindo adalah TBS. TBS diperoleh dari dua sumber yaitu kebun sendiri dan pembelian dari pihak ketiga. Karena bahan baku berasal dari kebun sendiri dan kebun lain, maka biaya pengadaan bahan baku dapat dibedakan menjadi biaya pengadaan bahan baku dari kebun sendiri dan biaya pembelian. Biaya produksi kelapa sawit yang terjadi di kebun sendiri terdiri dari Biaya tanaman untuk kegiatan produksi CPO dan Kernel dari kebun sendiri dan biaya pengolahan di Pabrik. Biaya pengadaan bahan baku dari kebun sendiri perkilogram TBS akan menjadi koefisien biaya dan biaya pembelian TBS per kilogram menjadi koefisien biaya kegiatan pengadaan bahan baku dari pembelian.

Koefisien fungsi tujuan yang digunakan dalam penelitian ini adalah harga jual setiap kilogram CPO dan Kernel yang dihasilkan dari PPKS sebagai penerimaan dan biaya pengadaan bahan baku baik dari kebun sendiri maupun pembelian dari pihak ketiga dan biaya pengolahan sebagai biaya produksi. Harga TBS yang diterapkan oleh PPKS Mega Sawindo mengikuti harga TBS yang ditetapkan di pasar (sesuai dengan SK Peraturan Menteri Pertanian Nomor 14/Permintan/OT.140/2013) dengan mempertimbangkan harga CPO dan Kernel serta rendemen CPO dan Kernel yang dikalikan dengan indeks nilai $\mathrm{K}$ yaitu proporsi yang menunjukkan bagian yang diterima oleh petani.

Biaya yang dimasukkan dalam perhitungan model adalah biaya produksi yang diperoleh langsung dari bagian produksi, sehingga fungsi tujuan dari model program linier untuk memaksimumkan keuntungan pada tahun 2016, sebagai berikut.

Maksimisasi:

$6326,36 \times 31+6526,40 \times 32+7583,68 \times 33+644$ $1,42 \times 34+6423,24 \times 35+6120,00 \times 36+6439,5$ $1 \mathrm{X} 37+7124,57 \mathrm{X} 38+6853,18 \mathrm{X} 39+7383,69 \mathrm{X}$ $310+8230,24 X 311+8690,91 \times 312+3030,889$ $\mathrm{X} 41+3222,02 \mathrm{X} 42+3508,77 \mathrm{X} 43+3576,76 \mathrm{X} 4$ $4+3709,88 X 45+3705,87 \mathrm{X} 46+3617,87 \mathrm{X} 47+4$ $070,33 X 48+4658,04 X 49+4913,04 X 410+511$ $7,57 \times 411+6621,93 \times 412-1170,68 \times 11-$ 
$1158,82 X 12-1282,22 \times 13-1237,80 \times 14-$

$1221,20 \times 15-1102,66 \times 16-1091,76 \times 17-$

1207,65X18-1268,50X19-1281,33X110-

1453,10X111-1353,44X112-1692,93X21-

1661,14X22-1877,96X23-1708,40X24-

$1699,02 \times 25-1740,79 \times 26-1574,72 \times 27-$

1701,28X28-1924,92X29-1815,17X210-

2197,30X211-2498,54X212-326,7X51-

265X52-387X53-252,2X54-279X55-

428,1X56-305,2X57-297X58-449,9X59-

289,7X510-446,6X511-613,2X512.

Keterangan :

X11-X112 = Biaya TBS yang berasal dari Kebun Sendiri bulan JanuariDesember

$\mathrm{X} 21-\mathrm{X} 212=$ Biaya TBS yang berasal dari Kebun Pihak ke III (Pembelian) bulan JanuariDesember

X31-X312 = Harga jual CPO dari PKS Mega Sawindo selama bulan Januari-Desember

X41-X412 = Harga jual Kernel dari PKS Mega Sawindo selama bulan Januari-Desember

X51-X512 = Biaya pengolahan TBS menjadi CPO dan Kernel dari bulan Januari-Desember

\section{Fungsi Kendala}

Kendala merupakan faktor pembatas bagi manajemen suatu perusahaan untuk mengambil keputusan produksi. Dalam optimalisasi CPO dan Kernel, kendala yang dimaksud yaitu kendala ketersediaan sumberdaya yang dimiliki perusahaan yang membatasi perusahaan dalam melakukan pengadaan bahan baku. Kendala dalam model program linier untuk optimalisasi CPO dan Kernel yang berasal dari alternatif sumber daya kebun dalam pengolahan TBS di Pabrik meliputi kapasitas produksi maksimal, kendala ketersediaan TBS pembelian, kendala kuota pembelian, dan ketersediaan tenaga kerja di Pabrik Pengolahan Kelapa Sawit PT. Mega Sawindo.

\section{Kendala Kapasitas Maksimal Pabrik}

Pengolahan TBS dipabrik kelapa sawit dimaksudkan untuk memperoleh CPO dari daging buah (mesocp) dan Kernel dari biji (nut). Untuk mendapat kualitas minyak yang baik bermula dari lapangan, sedangkan proses pengolahan di pabrik hanya dapat menekan sekecil mungkin perubahan/penurunan kualitas dan kehilangan (Lossis) selama proses. Pabrik tidak dapat memproduksi minyak lebih dari apa yang dikandung TBS. Mutu dan rendemen hasil olah sangat dipengaruhi oleh fraksi panen (derajat kematangan), kegiatan pengutipan brondolan dan perlakuan terhadap TBS. Perlakuan TBS mulai dari panen, transport dan proses pengolahan dipabrik akan menentukan kuantitas dan kualitas minyak yang dihasilkan PT. Mega Sawindo Perkasa memiliki kapasitas terpasang 80 ton/jam.

Koefisien fungsi yang digunakan dalam mengolah TBS adalah benilai satu karena kapasitas maksimal pabrik kelapa sawit sama. Nilai sebelah kanan kendala (right hand side) dari persamaan kendala ini merupakan hasil penggalian kapasitas pabrik (80 ton $/ \mathrm{jam}=80.000 \mathrm{Kg} / \mathrm{Jam})$ dengan waktu pengolahan (10 jam) dalam satu hari dan dikalikan dengan hari beroperasi dalam 1 bulan produksi (25 hari kerja) yaitu senilai 20.000.000. Berdasarkan uraian diatas model fungsi kendala kapasitas pabrik dapat dilihat pada Tabel 1.

\begin{tabular}{|c|c|c|}
\hline No. & Bulan & Kendala \\
\hline
\end{tabular}




\begin{tabular}{|l|l|l|}
1 & Januari & $\mathrm{X} 11+\mathrm{X} 21<=20.000 .000$ \\
\hline 2 & Februari & $\mathrm{X} 12+\mathrm{X} 22<=20.000 .000$ \\
\hline 3 & Maret & $\mathrm{X} 13+\mathrm{X} 23<=20.000 .000$ \\
\hline 4 & April & $\mathrm{X} 14+\mathrm{X} 24<=20.000 .000$ \\
\hline 5 & Mei & $\mathrm{X} 15+\mathrm{X} 25<=20.000 .000$ \\
\hline 6 & Juni & $\mathrm{X} 16+\mathrm{X} 26<=20.000 .000$ \\
\hline 7 & Juli & $\mathrm{X} 17+\mathrm{X} 27<=20.000 .000$ \\
\hline 8 & Agustus & $\mathrm{X} 18+\mathrm{X} 28<=20.000 .000$ \\
\hline 9 & September & $\mathrm{X} 19+\mathrm{X} 29<=20.000 .000$ \\
\hline 10 & Oktober & $\mathrm{X} 110+\mathrm{X} 210<=20.000 .000$ \\
\hline 11 & Nopember & $\mathrm{X} 1112+\mathrm{X} 211<=20.000 .000$ \\
\hline 12 & Desember & \\
\hline
\end{tabular}

Sumber : Hasil Penelitian, 2017

\section{Kendala Keterbatasan Ketersediaan Pembelian}

Bahan baku TBS yang diolah oleh pabrik kelapa sawit PT. Mega Sawindo berasal dari dua sumber yaitu TBS yang dihasilkan oleh kebun seinduk PT. Mega Sawindo Perkasa dan TBS dari pihak ketiga. Pihak ketiga PKS PT. Mega Sawindo Perkasa adalah masyarakat sekitar dan perkebunan swasta yang berada tidak jauh dari PKS PT. Mega Sawindo. Data pasokan TBS tahun 20016 yang berasal dari kebun pihak ketiga dapat memasok mencapai 55 persen dari total pasokan bahan baku TBS. Kemampuan pihak ketiga untuk memasok TBS sebesar 55 persen juga merupakan kendala yang dihadapi perusahaan. Oleh karena itu koefisien fungsi kendala yang digunakan adalah 55, yang sama nilainya setiap bulan. Adapun model fungsi kendala dari ketersediaan kebun pihak ketiga/pembelian 55 persen dapat dilihat kedua pada Tabel 2.

Tabel 2. Kendala Ketersediaan TBS Pembelian 55 Persen dari Kebun sendiri

\begin{tabular}{|c|l|c|}
\hline No. & \multicolumn{1}{|c|}{ Bulan } & Kendala \\
\hline 1 & Januari & $0,55 \times 21-0,45 \times 11<=0$ \\
\hline 2 & Februari & $0,55 \times 22-0,45 \times 12<=0$ \\
\hline 3 & Maret & $0,55 \times 23-0,45 \times 13<=0$ \\
\hline 4 & April & $0,55 \times 24-0,45 \times 14<=0$ \\
\hline 5 & Mei & $0,55 \times 25-0,45 \times 15<=0$ \\
\hline 6 & Juni & $0,55 \times 26-0,45 \times 16<=0$ \\
\hline 7 & Juli & $0,55 \times 27-0,45 \times 17<=0$ \\
\hline 8 & Agustus & $0,55 \times 28-0,45 \times 18<=0$ \\
\hline 9 & September & $0,55 \times 29-0,45 \times 19<=0$ \\
\hline 10 & Oktober & $0,55 \times 210-0,45 \times 110<=0$ \\
\hline 11 & Nopember & $0,55 \times 211-0,45 \times 111<=0$ \\
\hline 12 & Desember & $0,55 \times 212-0,45 \times 112<=0$ \\
\hline
\end{tabular}

Sumber : Hasil Penelitian, 2017

\section{Kendala Kuota Pembelian}

Pemenuhan kebutuhan bahan baku TBS, PT.

Mega Sawindo Perkasa menetapkan kebijakan batas maksimal pembelian TBS dari pihak ketiga setiap harinya sebesar 400 ton, maka batasan pasokan maksimal setiap bulannya sebesar 10.000 ton selama 25 hari kerja. Kebijakan ini dilakukan untuk menjamin kontinuitas produksi pabrik kelapa sawit untuk mengoptimalkan kuantitas CPO dan Kernel yang dihasilkan. Kuota pembelian ini dapat diambil sepenuhnya ataupun kurang dari batas kuota, sesuai kebutuhan PPKS dan jumlah pasokan dari kebun seinduk PT. Mega Sawindo Perkasa.

Kuota pembelian ini merupakan kendala dalam mencapai tujuan perusahaan yaitu memaksimumkan keuntungan. Adapun model fungsi kendala dari penetapan kuota pembelian PPKS dapat dilihat pada Tabel 3

Tabel 3. Kendala Kuota Pembelian TBS dari Kebun Pembelian Tahun 2016

\begin{tabular}{|c|l|c|}
\hline No. & \multicolumn{1}{|c|}{ Bulan } & Kendala \\
\hline 1 & Januari & X21 $<=10000000$ \\
\hline 2 & Februari & X22 $<=10000000$ \\
\hline 3 & Maret & $X 23<=10000000$ \\
\hline 4 & April & $X 24<=10000000$ \\
\hline 5 & Mei & $X 25<=10000000$ \\
\hline 6 & Juni & $X 26<=10000000$ \\
\hline 7 & Juli & $X 27<=10000000$ \\
\hline 8 & Agustus & $X 28<=10000000$ \\
\hline 9 & September & $X 29<=10000000$ \\
\hline
\end{tabular}




\begin{tabular}{|l|l|l|}
\hline 10 & Oktober & X210<=10000000 \\
\hline 11 & Nopember & X211<=10000000 \\
\hline 12 & Desember & X212<=10000000 \\
\hline
\end{tabular}

Sumber : Hasil Penelitian, 2017

\section{Kendala Ketersediaan Tenaga Kerja Langsung}

Tenaga kerja (TK) yang bekerja dibidang pengolahan TBS terdiri dari 78 orang dan dibagi menjadi dua sift. TK penting diperhitungkan sebagai kendala karena bagian dari sumberdaya yang dimiliki perusahaan. Sumberdaya TK pengolahan merupakan sumberdaya yang melakukan kegiatan proses produksi. Adapun jumlah operator dan tenaga kerja yang bekerja di pabrik kelapa sawit PT. Mega Sawindo untuk mengolah TBS terbagi dalam dua shift yaitu Shift I (Pukul 07.30 - 12.30) dan Shift II (Pukul 13.30 - bahan baku habis)

Tabel 4. Pasokan Bahan Baku Tandan Buah Segar dari Kebun Sendiri dan Pembelian Pada Tahun 2016

\begin{tabular}{|l|c|c|c|}
\hline \multicolumn{1}{|c|}{ Bulan } & Kebun Sendiri ( Kg ) & Pembelian ( Kg ) & Total \\
\hline Januari & 10.252 .950 & 6.316 .540 & 16.569 .490 \\
\hline Februari & 8.466 .550 & 8.774 .760 & 17.241 .310 \\
\hline Maret & 8.354 .680 & 12.751 .370 & 21.106 .050 \\
\hline April & 7.960 .930 & 8.687 .800 & 16.648 .730 \\
\hline Mei & 8.747 .880 & 8.364 .140 & 17.112 .020 \\
\hline Juni & 9.775 .260 & 7.545 .000 & 17.320 .260 \\
\hline Juli & 9.198 .340 & 4.801 .130 & 13.999 .470 \\
\hline Agustus & 11.415 .060 & 8.233 .100 & 19.648 .160 \\
\hline September & 15.090 .330 & 7.705 .250 & 22.795 .580 \\
\hline Oktober & 20.303 .230 & 14.911 .050 & 35.214 .280 \\
\hline Nopember & 18.404 .870 & 15.085 .340 & 3.490 .210 \\
\hline Desember & 16.880 .080 & 6.277 .870 & 23.157 .950 \\
\hline
\end{tabular}

Sumber : Hasil Penelitian, 2017

Nilai ruas kanan merupakan ketersediaan tenaga kerja yang dimiliki oleh PPKS PT. Mega Sawindo Perkasa adalah 1950 HOK perbulan. Koefisien fungsi kendala pada ketersediaan tenaga kerja merupakan hasil perbandingan jumlah $\mathrm{HOK}$ yang dimiliki PPKS PT. Mega Sawindo dengan total
TBS yang dipasok dari masing-masing sumber yaitu kebun sendiri (X1) dan pembelian dari pihak ketiga (X2) yang diolah di PPKS PT. Mega Sawindo pada setiap bulannya. Rumusan model kendala tenaga kerja dapat dilihat pada Tabel 5.

Tabel 5. Kendala Ketersediaan Tenaga Kerja di PPKS PT. Mega Sawindo Tahun 2016

\begin{tabular}{|c|c|c|c|c|c|c|c|c|}
\hline No. & Bulan & \multicolumn{7}{|c|}{ Kendala } \\
\hline 1 & Januari & 0,00019 & $\mathrm{X} 11$ & + & 0,00031 & X21 & $<=$ & 1.950 \\
\hline 2 & Februari & 0,00023 & $\mathrm{X} 12$ & + & 0,00022 & X22 & $<=$ & 1.950 \\
\hline 3 & Maret & 0,00023 & $\mathrm{X} 13$ & + & 0,00015 & $\mathrm{X} 23$ & $<=$ & 1.950 \\
\hline 4 & April & 0,00024 & X14 & + & 0,00022 & X24 & $<=$ & 1.950 \\
\hline 5 & Mei & 0,00022 & $\mathrm{X} 15$ & + & 0,00023 & $\mathrm{X} 25$ & $<=$ & 1.950 \\
\hline 6 & Juni & 0,00020 & X16 & + & 0,00026 & X26 & $<=$ & 1.950 \\
\hline 7 & Juli & 0,00021 & $\mathrm{X} 17$ & + & 0,00041 & $\mathrm{X} 27$ & $<=$ & 1.950 \\
\hline 8 & Agustus & 0,00017 & $\mathrm{X} 18$ & + & 0,00024 & X28 & $<=$ & 1.950 \\
\hline 9 & September & 0,00013 & X19 & + & 0,00025 & X29 & $<=$ & 1.950 \\
\hline 10 & Oktober & 0,00010 & $\mathrm{X} 110$ & + & 0,00013 & $\mathrm{X} 210$ & $<=$ & 1.950 \\
\hline 11 & Nopember & 0,00011 & X111 & + & 0,00013 & $\mathrm{X} 211$ & $<=$ & 1.950 \\
\hline 12 & Desember & 0,00012 & X112 & + & 0,00031 & $\mathrm{X} 212$ & $<=$ & 1.950 \\
\hline
\end{tabular}

Sumber : Hasil Penelitian, 2017

\section{Transfer CPO}

Kendala transfer merupakan Kendala transfer matematika agar model memungkinkan mengadakan transfer suatu kegiatan terhadap kegiatan lain. Dalam penelitian ini yang menjadi kendala transfer adalah transfer olah yaitu kegiatan pengolahan TBS menjadi CPO dan Kernel (Kernel) di pabrik pengolahan kelapa sawit (PPKS) PT. Mega Sawindo. Koefisien fungsi kendala transfer TBS menjadi CPO adalah batasan rendemen yang dihasilkan oleh TBS menjadi CPO pada setiap bulan. Tingkat rendemen merupakan salah satu indikator penentu mutu produksi CPO dan Kernel yang 
Tabel 6. Rendemen CPO dari TBS Kebun Sendiri dan Pembelian Tahun 2016

\begin{tabular}{|l|c|c|c|}
\hline \multicolumn{1}{|c|}{ Bulan } & Kebun Sendiri & Pembelian & Gabungan \\
\hline Januari & 24,15 & 22,65 & 23,40 \\
\hline Februari & 24,32 & 20,48 & 22,40 \\
\hline Maret & 24,16 & 18,82 & 21,49 \\
\hline April & 24,19 & 19,09 & 21,64 \\
\hline Mei & 24,15 & 18,87 & 21,51 \\
\hline Juni & 24,15 & 19,09 & 21,62 \\
\hline Juli & 23,97 & 17,79 & 20,88 \\
\hline Agustus & 24,2 & 15,46 & 19,83 \\
\hline September & 24,2 & 18,39 & 21,30 \\
\hline Oktober & 24,28 & 18,50 & 21,39 \\
\hline Nopember & 24,21 & 17,63 & 20,92 \\
\hline Desember & 24,12 & 20,95 & \\
\hline Sumber : Hasil Penelitian, 2017 & & & 2,54 \\
\hline
\end{tabular}

\section{Transfer Kernel}

TBS selain menghasilkan CPO juga dapat menghasilkan Kernel. Rendemen Kernel dihasilkan dari minyak yang ada dalam endosperm matang dan secara komersial biasanya di ekstrak secara terpisah.
Persentasi rendemen Kernel lebih kecil dibandingkan CPO karena pada umumnya dalam satu buah kelapa sawit hanya memiliki satu inti/Kernel (endosperm) yang padat dan sebuah embrio.

Tabel 7. Rendemen Kerneldari TBS Kebun Sendiri dan Pembelian Tahun 2016

\begin{tabular}{|l|c|c|c|}
\hline \multicolumn{1}{|c|}{ Bulan } & Kebun Sendiri & Pembelian & Gabungan \\
\hline Januari & 5,68 & 4,90 & 5,29 \\
\hline Februari & 5,36 & 5,00 & 5,18 \\
\hline Maret & 5,48 & 5,00 & 5,24 \\
\hline April & 5,48 & 4,90 & 5,19 \\
\hline Mei & 4,86 & 4,66 & 4,76 \\
\hline Juni & 4,51 & 4,31 & 4,41 \\
\hline Juli & 4,79 & 3,90 & 4,35 \\
\hline Agustus & 4,39 & 4,07 & 4,23 \\
\hline September & 4,89 & 4,30 & 4,59 \\
\hline Oktober & 5,10 & 4,59 & \\
\hline Nopember & 5,06 & 4,74 & \\
\hline Desember & 5,10 & 4,90 & \\
\hline
\end{tabular}

Sumber : Hasil Penelitian, 2017

Hasil Pemecahan Optimasi Produksi CPO dan Kernel pada PT. Mega Sawindo Perkasa

1. Kondisi aktual dan optimal bahan baku TBS

Analisis primal dilakukan untuk mengetahui kombinasi pengadaan bahan baku TBS dari tiap sumber dalam pengolahan CPO dan PK yang optimal untuk diproduksi pada PPKS PT. Mega Sawindo Perkasa sehingga diperoleh keuntungan yang maksimum. Hasil analisis primal diperoleh nilai optimal TBS PPKS PT. Mega Sawindo Perkasa dari kebun sendiri disajikan pada Tabel 8

Tabel 8. Nilai optimal TBS dari kebun sendiri Tahun 2016

\begin{tabular}{|l|c|c|c|}
\hline \multicolumn{1}{|c|}{ Bulan } & Nilai Aktual (Kg) & Nilai Optimal & Slisih (Kg) \\
\hline Januari & 10.252 .950 & 10.263 .158 & -10.208 \\
\hline Februari & 8.466 .550 & 8.478 .261 & -11.711 \\
\hline Maret & 8.354 .680 & 8.125 .000 & 229.680 \\
\hline April & 7.960 .930 & 8.863 .636 & -902.706 \\
\hline Mei & 8.747 .880 & 9.750 .000 & -1.002 .120 \\
\hline Juni & 9.775 .260 & 9.285 .714 & 489.546 \\
\hline Juli & 9.198 .340 & 11.470 .588 & -2.272 .248 \\
\hline Agustus & 11.415 .060 & 15.000 .000 & -3.584 .940 \\
\hline September & 15.090 .330 & 19.500 .000 & -4.409 .670 \\
\hline Oktober & 20.303 .230 & 17.727 .272 & 2.575 .958 \\
\hline Nopember & 18.404 .870 & 16.250 .000 & 2.154 .870 \\
\hline Desember & 16.880 .080 & 8.478 .261 & \\
\hline Rata-Rata & 12.070 .847 & 11.932 .658 & \\
\hline Sul & \\
\hline
\end{tabular}

Sumber : Hasil Penelitian, 2017

Tabel 9. Nilai optimal TBS dari Kebun Swasta (Pembelian) Tahun 2016

\begin{tabular}{|c|c|c|c|}
\hline Bulan & Nilai Aktual $(\mathrm{Kg})$ & Reduce Cost $(\mathrm{Kg})$ \\
\hline
\end{tabular}




\begin{tabular}{|l|c|c|c|}
\hline Januari & 6.316 .540 & 0.000000 & 975 \\
\hline Februari & 8.774 .760 & 0.000000 & 738 \\
\hline Maret & 12.751 .370 & 0.000000 & 759 \\
\hline April & 8.687 .800 & 0.000000 & 776 \\
\hline Mei & 8.364 .140 & 0.000000 & 847 \\
\hline Juni & 7.545 .000 & 0.000000 & 118 \\
\hline Juli & 4.801 .130 & 0.000000 & 1508 \\
\hline Agustus & 8.233 .100 & 0.000000 & 1415 \\
\hline September & 7.705 .250 & 0.000000 & 1652 \\
\hline Oktober & 14.911 .050 & 0.000000 & 1214 \\
\hline Nopember & 15.085 .340 & 0.000000 & 147 \\
\hline Desember & 6.277 .870 & 0.000000 & \\
\hline Rata-Rata & 9.121 .113 & 0.000000 & \\
\hline
\end{tabular}

Sumber : Hasil Penelitian, 2017

\section{Penggunaan Sumberdaya}

Analisis dual memberikan informasi terkait dengan ketersediaan serta penggunaan sumberdaya dengan melihat slack atau surplus serta dual pricenya. Nilai sumberdaya yang terbatas dinyatakan dengan nilai slack/surplus yang sama dengan nol. Kendala yang memiliki nilai seperti ini sering disebut kendala aktif. Sedangkan, kendala yang memiliki dual price sama dengan nol biasanya akan memiliki nilai slack/surplus. Kendala yang memiliki nilai seperti ini disebut dengan kendala pasif. Hal ini dikarenakan pengurangan atau penambahan ketersediaan kendala masih berada dalam selang yang diperbolehkan tidak akan mempengaruhi nilai keuntungan optimal perusahaan. Nilai slack/surplus menunjukkan penggunaan sumberdaya untuk menghasilkan kombinasi produksi pada keadaan optimal.

Nilai dual price adalah nilai sumberdaya yang menunjukkan besarnya pengaruh pengurangan ataupun penambahan ketersediaan sumberdaya terhadap nilai fungsi tujuan. Nilai dual price yang positif pada sumberdaya terbatas menunjukkan bahwa setiap penambahan ketersediaan sumberdaya sebesar satu satuan maka akan meningkatkan nilai fungsi tujuan sebesar nilai dual price tersebut. Sedangkan, nilai dual price yang negatif pada sumberdaya terbatas menunjukkan bahwa sebenarnya ketersediaan kendala pada formulasi model mengalami kelebihan, sehingga penurunan ketersediaan kendala sebesar satu satuan akan mengurangi nilai fungsi tujuan sebesar nilai dual price-nya. Analisis dual pada penelitian ini dilakukan untuk melihat jumlah pemanfaatan sumber daya yang dimiliki PKS PT. Mega Sawindo Perkasa, kebun sendiri dan pasokan dari pihak ketiga yang digunakan untuk memproduksi CPO dan Kernel pada kondisi model aktual.

\section{Penggunaan Kapasitas Pabrik}

Pabrik merupakan sumberdaya yang dimanfaatkan untuk mengolah TBS menjadi CPO dan Kernel. Penggunaan kapasitas pabrik pada kondisi aktual diperoleh dari perhitungan kapasitas pabrik dikurangi dengan nilai slack/surplus yang dihasilkan pada analisis dual model Lindo. Persentase pemanfaatan kapasitas diperoleh dari pembagian penggunaan kapasitas pabrik pada kondisi aktual dengan jumlah kapasitas pabrik setiap bulannya.

Tabel 10. Alokasi Pemanfaatan Optimal Kapasitas Pabrik PT. Mega Sawindo Perkasa Tahun 2016

\begin{tabular}{|l|c|c|c|}
\hline \multicolumn{1}{|c|}{ Bulan } & Kapasitas Pabrik (Kg) & Pemanfaatan Kapasitas Pabrik Aktual (Kg) & Persen tase (\%) \\
\hline Januari & 20.000 .000 & 10.263 .158 & 51 \\
\hline Februari & 20.000 .000 & 8.478 .261 & 42 \\
\hline Maret & 20.000 .000 & 8.478 .261 & 42 \\
\hline April & 20.000 .000 & 8.125 .000 & 41 \\
\hline Mei & 20.000 .000 & 8.863 .636 & 44 \\
\hline Juni & 20.000 .000 & 9.750 .000 & 49 \\
\hline Juli & 20.000 .000 & 9.285 .714 & 46 \\
\hline Agustus & 20.000 .000 & 11.470 .588 & 57 \\
\hline September & 20.000 .000 & 15.000 .000 & 75 \\
\hline Oktober & 20.000 .000 & 19.500 .001 & 98 \\
\hline Nopember & 20.000 .000 & 17.727 .273 & 89 \\
\hline Desember & 20.000 .000 & 16.250 .001 & 81 \\
\hline Rata-Rata & 20.000 .000 & 11.932 .658 & \\
\hline Sumbr & & & \\
\end{tabular}

Sumber : Hasil Penelitian, 2017

\section{Sumberdaya TBS Pembelian}

Analisis dual juga menunjukkan alokasi penggunaan sumberdaya bahan baku yang berasal dari pihak ketiga menjadi kendala dalam model.

Tabel 11. Hasil Analisis Pasokan Bahan Baku TBS dari Pihak Ketiga Pada Kondisi Model Aktual 


\begin{tabular}{|l|c|c|c|}
\hline \multicolumn{1}{|c|}{ Bulan } & Diolah & Slack/Surplus & Dual Price \\
\hline Januari & 1.698 .119 & 4.618 .421 & 0.000000 \\
\hline Februari & 4.959 .543 & 3.815 .217 & 0.000000 \\
\hline Maret & 8.936 .153 & 3.815 .217 & 0.000000 \\
\hline April & 5.031 .550 & 3.656 .250 & 0.000000 \\
\hline Mei & 4.375 .504 & 3.988 .636 & 0.000000 \\
\hline Juni & 3.157 .500 & 4.387 .500 & 0.000000 \\
\hline Juli & 622.559 & 4.178 .572 & 0.000000 \\
\hline Agustus & 3.071 .336 & 5.161 .765 & 0.000000 \\
\hline September & 955.250 & 6.750 .000 & 0.000000 \\
\hline Oktober & 6.136 .050 & 8.775 .000 & 0.000000 \\
\hline Nopember & 7.108 .068 & 7.977 .273 & 0.000000 \\
\hline Desember & - & 7.312 .500 & 0.000000 \\
\hline Rata-Rata & 4.186 .512 & 5.369 .696 & 0.000000 \\
\hline
\end{tabular}

Sumber : Hasil Penelitian, 2017

\section{Kuota Pembelian TBS}

Kebijakan perusahaan menetapkan batasan kuota pembelian TBS dari pihak ketiga bertujuan untuk mengoptimalkan keuntungan PKS dengan tetap menjaga kontinuitas proses produksi. Kuota pembelian didukung oleh ketersediaan kebun sendiri dalam memenuhi sebagian besar kebutuhan TBS di PKS PT. Mega Sawindo. Batasan kuota dibuat untuk melindungi perusahaan dalam pemenuhan bahan baku produksi. Kuota pembelian TBS maksimum $10.000 .000 \mathrm{~kg}$.

\section{Ketersediaan Tenaga Kerja Langsung}

Tenaga kerja langsung merupakan tenaga kerja tetap yang melakukan kegiatan tahapan-tahapan proses produksi baik CPO maupun Kernel.

Tabel 13. Analisis Ketersediaan Tenaga Kerja Pada Kondisi Model Aktual

\begin{tabular}{|l|c|c|}
\hline \multicolumn{1}{|c|}{ Bulan } & Dual Price & Slack/Surplus \\
\hline Januari & 0.000000 & 2.785 .739 \\
\hline Februari & 0.000000 & 2.613 .482 \\
\hline Maret & 0.000000 & 3.227 .295 \\
\hline April & 0.000000 & 2.151 .608 \\
\hline Mei & 0.000000 & 2.319 .603 \\
\hline Juni & 0.000000 & 2.712 .274 \\
\hline Juli & 0.000000 & 4.089 .314 \\
\hline Agustus & 0.000000 & 2.976 .603 \\
\hline September & 0.000000 & 4.751 .906 \\
\hline Oktober & 0.000000 & 7.619 .950 \\
\hline Nopember & 0.000000 & 7.258 .092 \\
\hline Desember & 0.000000 & 9.004 .383 \\
\hline Rata-Rata & 0.000000 & 4.292 .521 \\
\hline
\end{tabular}

Sumber : Hasil Penelitian, 2017

Berdasarkan Tabel 13 dapat diketahui bahwa ketersediaan tenaga kerja pengolahan memiliki nilai slack/surplus sama dengan nol dan nilai dual price lebih dari nol (positif) untuk setiap bulan pada tahun 2016, sehingga secara keseluruhan sudah termanfaatkan secara penuh. Rataan nilai dual price untuk kendala tenaga kerja sebesar Rp 4.291.521 menunjukan bahwa jika ketersediaan tenaga kerja ditambah atau meningkatkan jumlah satu HOK tiap bulannya, maka PKS PT. Mega Sawindo memiliki peluang untuk meningkatkan keuntungan sebesar Rp 4.291.521 (Cateris Paribus).

\section{Transfer Pengolahan TBS menjadi CPO}

Pengolahan TBS menjadi CPO melewati berbagai proses produksi. Untuk melihat kendala transfer TBS menjadi CPO pada kondisi model aktual akan disajikan pada Tabel 14.

Tabel 14. Analisis Transfer TBS menjadi CPO Pada Kondisi Model Aktual

\begin{tabular}{|l|c|c|}
\hline \multicolumn{1}{|c|}{ Bulan } & Slack/Surplus & Dual Price \\
\hline Januari & 0.000000 & 6326 \\
\hline Februari & 0.000000 & 6526 \\
\hline Maret & 0.000000 & 7584 \\
\hline April & 0.000000 & 6441 \\
\hline Mei & 0.000000 & 6423 \\
\hline Juni & 0.000000 & 6120 \\
\hline Juli & 0.000000 & 6440 \\
\hline Agustus & 0.000000 & \\
\hline
\end{tabular}




\begin{tabular}{|l|c|c|}
\hline September & 0.000000 & 6853 \\
\hline Oktober & 0.000000 & 7384 \\
\hline Nopember & 0.000000 & 8230 \\
\hline Desember & 0.000000 & 8691 \\
\hline Rata-Rata & 0.000000 & 12.355 \\
\hline
\end{tabular}

Sumber : Hasil Penelitian, 2017

Transfer Pengolahan TBS menjadi Kernel

Pengolahan TBS menjadi Kernel melewati berbagai proses produksi. Untuk melihat kendala transfer TBS menjadi Kernel pada kondisi model aktual dapat dilihat pada Tabel 15 .

Tabel 15. Analisis Transfer TBS menjadi Kernel Pada Kondisi Model Aktual

\begin{tabular}{|l|c|c|}
\hline \multicolumn{1}{|c|}{ Bulan } & Slack/Surplus & Dual Price \\
\hline Januari & 0.000000 & 3031 \\
\hline Februari & 0.000000 & 3222 \\
\hline Maret & 0.000000 & 3509 \\
\hline April & 0.000000 & 3577 \\
\hline Mei & 0.000000 & 3710 \\
\hline Juni & 0.000000 & 3706 \\
\hline Juli & 0.000000 & 3618 \\
\hline Agustus & 0.000000 & 4070 \\
\hline September & 0.000000 & 4658 \\
\hline Oktober & 0.000000 & 4913 \\
\hline Nopember & 0.000000 & 5118 \\
\hline Desember & 0.000000 & 6622 \\
\hline Rata-Rata & 0.000000 & 4.146 \\
\hline
\end{tabular}

Sumber : Hasil Penelitian, 2017

\section{Keuntungan Optimal Perusahaan}

Untuk melihat selisih keuntungan pada kondisi aktual dan kondisi optimal disajikan pada Tabel 16.

Tabel 16. Selisih Keuntungan pada Kondisi Aktual dan Kondisi Optimal

\begin{tabular}{|c|c|c|}
\hline No & Keterangan & Keuntungan \\
\hline 1 & Keadaan optimal perusahaan & Rp 100.445.000.000,00 \\
\hline 2 & Keadaan aktual perusahaan & $\begin{array}{cc}\operatorname{Rp} & 71.385 .112 .115,04\end{array}$ \\
\hline 3 & Selisih & $\begin{array}{ll}\text { Rp } & 29.059 .887 .884,96 \\
\end{array}$ \\
\hline 4 & Optimal Keuntungan & $40,71 \%$ \\
\hline
\end{tabular}

Sumber : Hasil Penelitian, 2017

Berdasarkan hasil olahan data pada Tabel 16, menunjukan bahwa kondisi aktual yang dialami oleh perusahaan memiliki selisih cukup besar yaitu Rp 29.059.887.884,96 dibandingkan kondisi optimalnya atau dapat dikatakan 40,71 \% dapat dioptimalkan melalui linear progamming. Total perolehan laba kotor dari pengadaan bahan baku TBS dan pengolahan TBS aktual pada tahun 2016 sebesar Rp71.385.112.115,04, sedangkan pada kondisi optimal perusahaan mampu memperoleh laba sebesar Rp 100.445.000.000. Adanya perbedaan besar laba kotor pengadaan bahan baku dan pengolahan TBS dari masing-masing kebun dalam kondisi aktual dan optimal, perusahaan sebaiknya melakukan optimalisasi pengadaan bahan baku TBS dan pengolahan sesuai dengan kondisi optimal. Selisih nilai keuntungan antara optimal dan aktual diakibatkan oleh adanya sumberdaya-sumberdaya yang berlebih atau tidak dimanfaatkan secara optimal seperti kapasitas pabrik, TBS, pembelian yang mengakibatkan pemborosan biaya pengadaan TBS dan biaya pengolahan.

\section{Analisis Sensitivitas}

Sensitivitas dilakukan untuk mengetahui sejauh mana perubahan variabel keputusan dan kendala terhadap pencapaian nilai variabel tujuan. Pengaruh perubahan dapat dilihat dari selang kepekaan yang terdiri atas batas minimum (allowable decrease) dan batas maksimum (allowable increase). Analisis sensitivitas yang terdapat pada hasil olahan dengan menggunakan program LINDO terdiri atas dua bagian yaitu analisis sensitivitas nilai fungsi tujuan dan analisis sensitivitas ruas kanan kendala. Semakin sempit nilai selang kepekaan maka akan semakin peka hasil solusi optimal pada model Linear Program (LP) terhadap perubahan. Berikut ini akan dijelaskan analisis sensitivitas nilai koefisien fungsi tujuan dan analisis sensitivitas nilai ketersediaan kendala (RHS).

\section{Analisis Sensitivitas Fungsi Tujuan}


Analisis sensitivitas terhadap fungsi tujuan digunakan untuk melihat selang perubahan harga $\mathrm{CPO}$ dan Kernel, biaya TBS dan biaya pengolahan CPO dan Kernel yang masih diizinkan agar solusi optimal dalam perencanaan pengadaan bahan baku tetap berlaku dengan parameter lain dianggap konstan. Selang perubahan yang dihasilkan dapat dilihat dari nilai yang terdapat pada kolom allowable increase dan allowable decrease yang diambil dari nilai olahan LINDO pada tahun 2016. Analisis sensitivitas selain dapat mengatahui selang perubahan koefisien fungsi tujuan yang tetap mempertahankan kondisi optimal, juga dapat mengetahui kepekaan suatu variabel. Untuk melihat analisis sensitivitas nilai biaya bahan baku TBS dari kebun sendiri dapat dilihat pada Tabel 17.

Tabel 17. Analisis Sensitivitas Nilai Biaya Bahan Baku TBS Kebun Sendiri

\begin{tabular}{|l|c|c|c|}
\hline \multicolumn{1}{|c|}{ Bulan } & Koefesien & Batas Kenaikan yang diperboleh kan & Batas Penurunan Yang diperbolehkan \\
\hline Januari & 1170,68 & INFINITY & 529 \\
\hline Februari & 1158,81 & INFINITY & 601 \\
\hline Maret & 1282,21 & INFINITY & 742 \\
\hline April & 1237,8 & INFINITY & 516 \\
\hline Mei & 1221,19 & INFINITY & 510 \\
\hline Juni & 1102,66 & INFINITY & 542 \\
\hline Juli & 1091,76 & INFINITY & 625 \\
\hline Agustus & 1207,65 & INFINITY & 695 \\
\hline September & 1268,5 & INFINITY & 618 \\
\hline Oktober & 1.281 & $I N F I N I T Y$ & 762 \\
\hline Nopember & 1453,09 & $I N F I N I T Y$ & 798 \\
\hline Desember & 1353,43 & $I N F I N I T Y$ & 1081 \\
\hline
\end{tabular}

Sumber : Hasil Penelitian, 2017

Berdasarkan Tabel 17 diatas dapat diketahui bahwa peningkatan harga CPO, Kernel dan biaya pengadaan bahan baku dari kebun sendiri secara kesuluruhan memiliki batasan kenaikan nilai harga/biaya yang tidak terhingga (infinity) dan batas penurunan harga/biaya yang diperbolehkan sebesar nilai tertentu.

Hasil analisis sensitivitas fungsi tujuan menunjukkan bahwa harga CPO, Kernel dan biaya pengadaan TBS dari kebun sendiri tidak memiliki selang kepekaan kenaikan. Sementara biaya pengadaan TBS dari pihak ketiga memiliki selang kepekaan penurunan. Adapun analisis sensitif pada pihak ketiga (swasta) atau pembelian dapat dilihat pada Tabel 18 berikut :

Tabel 18. Analisis Sensitivitas Nilai Biaya Bahan Baku TBS Swasta (Pembelian)

\begin{tabular}{|l|c|c|c|}
\hline \multicolumn{1}{|c|}{ Bulan } & Koefesien & Batas Kenaikan yang diperbolehkan & Batas Penurunan Yang diperboleh kan \\
\hline Januari & 1692,93 & 975 & INFINITY \\
\hline Februari & 1661,14 & 738 & INFINITY \\
\hline Maret & 1877,95 & 759 & INFINITY \\
\hline April & 1708,4 & 777 & INFINITY \\
\hline Mei & 1699,02 & 847 & $I N F I N I T Y$ \\
\hline Juni & 1740,79 & 1118 & $I N F I N I T Y$ \\
\hline Juli & 1574,71 & 1508 & INFINITY \\
\hline Agustus & 1924,92 & 1415 & $I N F I N I T Y$ \\
\hline September & 1701,28 & 1652 & $I N F I N I T Y$ \\
\hline Oktober & 1815,17 & 1214 & $I N F I N I T Y$ \\
\hline Nopember & 2197,3 & 1447 & $I N F I N I T Y$ \\
\hline Desember & 2498,54 & 3145 & $I N F I N I T Y$ \\
\hline
\end{tabular}

Sumber : Hasil Penelitian, 2017

2. Analisis Sensitivitas Nilai Ruas Kanan Kendala

Analisis sensitivitas ruas kanan kendala atau sering disebut dengan Right Hand Side (RHS) berkaitan dengan status sumberdaya yang bersangkutan dalam mengoptimalkan pengadaan bahan baku produksi CPO dan Kernel. Apabila suatu sumberdaya merupakan kendala pembatas, maka sumberdaya tersebut memiliki nilai kenaikan dan penurunan sebesar nilai hasil analisis sensitivitasnya. Sebaliknya, jika sumberdaya tersebut merupakan kendala bukan pembatas, maka akan memiliki nilai kenaikan yang tidak terbatas (Infinity) penurunan sebesar nilai slack/surplus yang diperoleh. Nilai batas atas yang diperoleh adalah hasil penjumlahan dari batas peningkatan dengan ketersediaan sumberdaya 
yang dimiliki dari masing-masing kebun, sedangkan batas bawah adalah pengurangan dari ketersediaan dengan batas penurunannya. Besarnya perubahan dari kapasitas kendala ini akan sebanding dengan kontribusi yang diterima dari nilai dual pricenya, selama perubahan tersebut berada dalam selang

Tabel 19. Analisis Sensitivitas Ruas Kanan Kendala Pengadaan Bahan Baku TBS di PKS PT. Mega Sawindo Perkasa

\begin{tabular}{|c|l|c|c|c|c|}
\hline No & $\begin{array}{c}\text { Sumber Kendala Bahan Baku } \\
\text { Pengadaan TBS }\end{array}$ & Nilai RHS & Allow able Increase & Allow able Decrease & Status \\
\hline 1 & Kapasitas Maksimum Pabrik & 20.000 .000 & INFINITY & 8.067 .342 & \\
\hline 2 & Ketersediaan Pembelian TBS & 9.121 .113 & INFINITY & 5.369 .696 & BP \\
\hline 3 & Kuota Pembelian & 10.000 .000 & INFINITY & 10.000 .000 & 1.950 \\
\hline 4 & Tenaga Kerja & 1.950 & 1.633 & BP & P \\
\hline 5 & Transfer (CPO) & 4.561 .344 & INFINITY & 2.885 .582 & BP \\
\hline 6 & Transfer (Kernel) / Kernel & 1.025 .698 & INFINITY & 601.653 & BP \\
\hline
\end{tabular}

Keterangan : (BP) = Bukan Pembatas

$$
(\mathrm{P})=\text { Pembatas }
$$

a. Kepekaan Kapasitas Maksimal Pabrik Kelapa Sawit

Analisis sensitivitas nilai kapasitas maksimal kepekaan. Analisis sensitivitas dapat memperlihatkan selang perubahan pada ketersediaan sumberdaya atau RHS yang tidak menyebabkan perubahan pada nilai dual kendala yang bersangkutan. pabrik kelapa sawit yang digunakan untuk mengetahui sejauh mana perubahan kapasitas PKS dapat mengubah kondisi optimal.

Tabel 19. Analisis Sensitivitas Nilai Kendala Kapasitas Maksimal Pabrik

\begin{tabular}{|l|c|c|c|}
\hline \multicolumn{1}{|c|}{ Bulan } & Koefesien & Batas Kenaikan yang diperbolehkan & Batas Penurunan Yang Dierbolehkan \\
\hline Januari & 20.000 .000 & INFINITY & 9.736 .842 \\
\hline Februari & 20.000 .000 & INFINITY & 11.521 .739 \\
\hline Maret & 20.000 .000 & INFINITY & 11.521 .739 \\
\hline April & 20.000 .000 & $I N F I N I T Y$ & 11.875 .000 \\
\hline Mei & 20.000 .000 & INFINITY & 11.136 .364 \\
\hline Juni & 20.000 .000 & INFINITY & 10.250 .000 \\
\hline Juli & 20.000 .000 & INFINITY & 10.714 .286 \\
\hline Agustus & 20.000 .000 & INFINITY & 8.529 .412 \\
\hline September & 20.000 .000 & INFINITY & 5.000 .000 \\
\hline Oktober & 20.000 .000 & INFINITY & 499.999 \\
\hline Nopember & 20.000 .000 & $I N F I N I T Y$ & 2.272 .727 \\
\hline Desember & 20.000 .000 & $I N F I N I T Y$ & 3.749 .999 \\
\hline Rata-rata & 20.000 .000 & $I N F I N I T Y$ & 8.067 .342 \\
\hline
\end{tabular}

Sumber : Hasil Penelitian, 2017

Berdasarkan Tabel 19 dapat diketahui bahwa secara keseluruhan kendala kapasitas maksimal pabrik untuk produksi memproduksi CPO dan Kernel termasuk kendala berlebih dan bukan merupakan pembatas bagi PKS PT. Mega Sawindo. Hal ini dapat dilihat dengan adanya nilai tidak terhingga pada batas kenaikan perubahan ketersediaan dan adanya nilai pada batas penurunan sebesar angka yang tertera pada

Tabel 20. Hasil Analisis Sensitivitas Nilai Kendala Ketersediaan TBS Pembelian

Tabel 20. Hasil Analisis Sensitivitas Nilai Kendala Ketersediaan TBS Pembelian
\begin{tabular}{|l|c|c|c|}
\hline \multicolumn{1}{|c|}{ Bulan } & Pasoan TBS Swasta Aktual (Kg) & Batas Kenaikan yang diperbolehkan & Batas Penurunan Yang diperbolehkan \\
\hline Januari & 6.316 .540 & INFINITY & 4.618 .421 \\
\hline Februari & 8.774 .760 & INFINITY & 3.815 .217 \\
\hline Maret & 12.751 .370 & $I N F I N I T Y$ & 3.815 .217 \\
\hline April & 8.687 .800 & $I N F I N I T Y$ & 3.656 .250 \\
\hline Mei & 8.364 .140 & INFINITY & 3.988 .636 \\
\hline Juni & 7.545 .000 & INFINITY & 4.387 .500 \\
\hline Juli & 4.801 .130 & $I N F I N I T Y$ & 4.178 .572 \\
\hline Agustus & 8.233 .100 & $I N F I N I T Y$ & 5.161 .765 \\
\hline September & 7.705 .250 & $I N F I N I T Y$ & 6.750 .000 \\
\hline Oktober & 14.911 .050 & $I N F I N I T Y$ & 8.775 .000 \\
\hline
\end{tabular}

kolom batas penurunan yang diperbolehkan.

b. Kepekaan Ketersediaan TBS Pembelian

Analisis sensitivitas nilai ketersediaan pasokan TBS dari pihak ketiga yang digunakan untuk mengetahui sejauh mana perubahan jumlah TBS dari pihak ketiga dapat mengubah kondisi optimal dilihat pada Tabel 20. 


\begin{tabular}{|l|l|l|l|} 
Nopember & 15.085 .340 & INFINITY & 7.977 .272 \\
\hline Desember & 6.277 .870 & INFINITY & 7.312 .500 \\
\hline Rata-rata & 9.121 .113 & INFINITY & 5.369 .696 \\
\hline
\end{tabular}

Sumber : Hasil Penelitian, 2017

Berdasarkan Tabel 20 dapat dinyatakan bahwa ketersediaan pasokan TBS dari pihak ketiga juga bukan kendala pembatas bagi PKS PT. Mega Sawindo untuk mencapai keuntungan maksimum perusahaan. Dimana secara keseluruhan nilai batas kenaikan yang diperbolehkan menunjukkan nilai tak terhingga (infinity) artinya penambahan TBS dari pihak ketiga berapa pun jumlahnya tidak akan mempengaruhi nilai keuntungan yang diterima oleh PKS PT. Mega Sawindo. Pada kolom batas penurunan yang diperbolehkan menunjukkan angka yang berfluktuasi dengan nilai terbesar pada bulan
Oktober yaitu sebesar Rp. 8.775.000,- yang artinya bahwa penurunan bahan baku TBS dari pihak ketiga yang diperbolehkan agar produksi tetap optimal adalah sebesar Rp. 8.775.000 kilogram.

\section{c. Kepekaan Batasan Kuota Pembelian}

Analisis sensitivitas batasan kuota pembelian TBS dari pihak ketiga yang sesuai dengan kebijakan perusahaan. Kepekaan batasan kuota pembelian TBS pihak ketiga dapat digunakan untuk mengetahui sejauh mana perubahan nilai optimal yang akan diperoleh perusahaan.

Tabel 21. Hasil Analisis Sensitivitas Nilai Kuota Pembelian TBS Pada Kondisi

\begin{tabular}{|l|c|c|c|}
\hline \multicolumn{1}{|c|}{ Bulan } & Batas Kuota Pembelian (kg) & Batas Kenaikan yang diperbolehkan & Batas Penurunan yang diperbolehkan \\
\hline Januari & 10.000 .000 & $I N F I N I T Y$ & 10.000 .000 \\
\hline Februari & 10.000 .000 & $I N F I N I T Y$ & 10.000 .000 \\
\hline Maret & 10.000 .000 & $I N F I N I T Y$ & 10.000 .000 \\
\hline April & 10.000 .000 & $I N F I N I T Y$ & 10.000 .000 \\
\hline Mei & 10.000 .000 & $I N F I N I T Y$ & 10.000 .000 \\
\hline Juni & 10.000 .000 & $I N F I N I T Y$ & 10.000 .000 \\
\hline Juli & 10.000 .000 & $I N F I N I T Y$ & 10.000 .000 \\
\hline Agustus & 10.000 .000 & $I N F I N I T Y$ & 10.000 .000 \\
\hline September & 10.000 .000 & $I N F I N I T Y$ & 10.000 .000 \\
\hline Oktober & 10.000 .000 & $I N F I N I T Y$ & 10.000 .000 \\
\hline Nopember & 10.000 .000 & $I N F I N I T Y$ & 10.000 .000 \\
\hline Desember & 10.000 .000 & $I N F I N I T Y$ & 10.000 .000 \\
\hline
\end{tabular}

Sumber : Hasil Penelitian, 2017

Berdasarkan Tabel 21 di atas dapat dinyatakan bahwa batasan kuota pembelian TBS dari pihak ketiga ini merupakan kendala bukan pembatas bagi PKS Mega Sawindo untuk mencapai keuntungan maksimum perusahaan, dimana terlihat secara keseluruhan nilai batas kenaikan yang diperbolehkan untuk kendala batasan kuota pembelian TBS yang berasal dari pihak ketiga menunjukkan nilai tak terhingga (infinity) artinya penambahan batasan kuota pasokan TBS dari pihak ketiga berapa pun jumlahnya tidak akan mempengaruhi nilai keuntungan yang diterima oleh PKS PT. Mega Sawindo. Sedangkan batasan penurunan setiap bulannya sama dengan nilai batasan kuota yang ditetapkan oleh PKS PT. Mega Sawindo yang artinya batasan kuota secara actual boleh sama sekali tidak diambil atau perusahaan boleh tidak membeli sama sekali TBS dari pihak ketiga.

\section{d. Kepekaan Ketersediaan Tenaga Kerja Pengolahan}

Ketersediaan tenaga kerja dalam proses pengolahan sangat mempengaruhi hasil output perusahaan.

Tabel 22. Analisis Sensitivitas Nilai Ketersediaan Tenaga Kerja Pengolahan pada Kondisi Model Aktual

\begin{tabular}{|l|c|c|c|}
\hline \multicolumn{1}{|c|}{ Bulan } & Jumlah Tenaga Kerja (HOK) & Batas Kenaikan yang diperbolehkan & Batas Penurunan Yang diperbolehkan \\
\hline Januari & 1.950 & 1850 & 1.950 \\
\hline Februari & 1.950 & 2650 & 1.950 \\
\hline Maret & 1.950 & 2650 & 1.950 \\
\hline April & 1.950 & 2850 & 1.950 \\
\hline Mei & 1.950 & 2450 & 1.950 \\
\hline Juni & 1.950 & 2050 & 1.950 \\
\hline Juli & 1.950 & 2250 & 1.950 \\
\hline Agustus & 1.950 & 1450 & 1.950 \\
\hline September & 1.950 & 650 & 1.950 \\
\hline Oktober & 1.950 & 50 & 1.950 \\
\hline Nopember & 1.950 & 250 & 1.950 \\
\hline
\end{tabular}




\begin{tabular}{|l|c|c|c|} 
Desember & 1.950 & 450 & 1.950 \\
\hline Rata-Rata & 1.950 & 1633,31 & 1.950 \\
\hline
\end{tabular}

Sumber : Hasil Penelitian, 2017

Berdasarkan Tabel 22 dapat dilihat bahwa ketersediaan tenaga kerja merupakan kendala pembatas bagi PKS PT Mega Sawindo untuk mengoptimalkan keuntungan perusahaan. Hal ini dapat dilihat dari nilai-nilai tertentu pada keseluruhan kolom batas kenaikan yang diperbolehkan dan batas penurunan yang diperbolehkan. Nilai-nilai tersebut merupakan batasan baik penurunan maupun peningkatan yang diperbolehkan untuk mencapai tingkat keuntungan optimal perusahaan. Apabila batasan peningkatan berlebih dari nilai yang diperbolehkan hanya akan menimbulkan pemborosan tenaga kerja, sementara bila penurunan tenaga kerja dilakukan berlebih dari nilai yang diperbolehkan maka perusahaan tidak dapat mencapai nilai optimalnya.

e. Kepekaan Transfer TBS menjadi CPO

Adapun analisis sensitivitas nilai transfer TBS menjadi CPO dapat dilihat pada Tabel 23 berikut.

Tabel 23. Analisis Sensitivitas Nilai Transfer TBS Menjadi CPO

\begin{tabular}{|l|c|c|c|}
\hline \multicolumn{1}{|c|}{ Bulan } & Produksi CPO & Batas Kenaikan yang diperbolehkan & Batas Penurunan yang diperbolehkan \\
\hline Januari & 3.877 .060 & $I N F I N I T Y$ & 2.478 .553 \\
\hline Februari & 3.862 .330 & $I N F I N I T Y$ & 2.061 .913 \\
\hline Maret & 4.535 .640 & $I N F I N I T Y$ & 2.048 .348 \\
\hline April & 3.602 .530 & $I N F I N I T Y$ & 1.965 .438 \\
\hline Mei & 3.681 .190 & $I N F I N I T Y$ & 2.140 .568 \\
\hline Juni & 3.744 .470 & $I N F I N I T Y$ & 2.354 .625 \\
\hline Juli & 2.923 .170 & $I N F I N I T Y$ & 2.225 .786 \\
\hline Agustus & 3.896 .360 & $I N F I N I T Y$ & 2.775 .882 \\
\hline September & 4.854 .840 & $I N F I N I T Y$ & 3.630 .000 \\
\hline Oktober & 7.532 .840 & $I N F I N I T Y$ & 4.734 .600 \\
\hline Nopember & 7.006 .630 & $I N F I N I T Y$ & 4.291 .773 \\
\hline Desember & 5.219 .070 & $I N F I N I T Y$ & 3.919 .500 \\
\hline Rata-rata & 4.561 .344 & $I N F I N I T Y$ & 2.885 .582 \\
\hline
\end{tabular}

Sumber :Hasil Penelitian, 2017

Dari Tabel 23 dapat diketahui bahwa secara keseluruhan kendala transfer TBS menjadi CPO memiliki selang batasan kenaikan yang diperbolehkan tidak memeiliki batasan, sementara penurunan yang diperbolehkan memiliki nilai tertentu.

Nilai selang perubahan ini menggambarkan bahwa jika perubahan penurunan maupun peningkatan produksi CPO yang terkandung dalam TBS jika masih di antara nilai kedua batas nilai penurunannya atau antara nilai selang maka kondisi optimal masih bisa dipertahankan. Namun, apabila penurunan produksi CPO melebihi nilai penurunan yang diperbolehkan maka akan mengakibatkan penurunan nilai keuntungan optimal perusahaan. Hal ini menunjukkan bahwa perusahaan perlu menjaga kualitas rendemen CPO dari TBS yang dipasok. Semakin tinggi kandungan rendemen yang dihasilkan maka produksi CPO semakin banyak, yang kemudian dapat meningkatkan keuntungan perusahaan.

f. Kepekaan Transfer TBS menjadi Kernel

Kendala transfer TBS menjadi Kernel juga merupakan kendala pembatas bagi PKS PT. Mega Sawindo untuk mengoptimalkan keuntungan perusahaan. Rendemen TBS menghasilkan Kernel merupakan jumlah produksi Kernel yang dihasilkan dari setiap satu kilogram TBS.

\section{KESIMPULAN DAN SARAN}

\section{Kesimpulan}

1. Aktivitas produksi CPO dan Kernel pada PT. Mega Sawindo perkasa tahun 2016 belum mencapai kondisi optimal dapat dilihat dari keuntungan optimal dan aktual yang memiliki selisih Rp 29.059.887.884,96 yang berarti keuntungan perusahaan dapat ditingkatkan sebesar 40,71\% dari keuntungan yang diperoleh perusahaan.

2. Ketersediaan tenaga kerja langsung merupakan sumberdaya pembatas untuk mengoptimalkan keuntungan perusahaan sedangkan sumberdaya ketersediaan TBS pembelian dari pihak swasta, kuota pembelian, trasnsfer TBS menjadi CPO dan transfer TBS menjadi Kernel/Kernel mengalami kelebihan.

\section{Saran}

1. Perusahaan perlu meningkatkan pasokan dan kualitas bahan baku yang berasal dari kebun sendiri untuk memperoleh hasil yang maksimal dalam memenuhi kapasitas terpasang pabrik. 
2. Melakukan pembelian TBS dari pihak ketiga sesuai dengan kebutuhan PKS untuk mencapai keuntungan optimalnya.

3. Perusahaan perlu menyiapkan cadangan tenaga kerja untuk aktivitas sortasi dan produksi untuk mengantisipasi kekurangan tenaga kerja saat terjadi penambahan produksi.

\section{DAFTAR PUSTAKA}

Assauri, S. 1993. Managemen Produksi dan Operasi. Lembaga Penerbit Fakultas Ekonomi Universitas Indonesia. Jakarta

Aulia, P. 2006. Analisis Optimasi Produksi Susu Kental Manis (SKM). Skripsi. Fakultas Pertanian Universitas Lampung. Bandar Lampung

Badan Pusat Statistik (BPS) Pusat. 2015.Statistik Kelapa Sawit Indonesia. Badan Pusat Statistik (BPS) Pusat. Jakarta

Lathifah, M. A. 2006. Optimalisasi Produksi Cocoa Butter Dan Cocoa Powder Pada PT. Cacao Wangi Murni Tangerang. Skripsi. Fakultas Pertanian Institut Pertanian Bogor. Bogor http://repository.ipb.ac.id/handle/123456789/ 12394 diakses tanggal 21 April 2017 pukul 02.30 wib

Marsaulina, K. S.1999. Analisis Optimalisasi Produksi Crude Palm Oil (CPO) Dan Palm Kernel (PK) Study Kasus Pada PT. Perkebunan Nusantara XIII (Persero) Kalimantan Barat. Skripsi. Fakultas Pertanian Institut Pertanian Bogor. Bogor http://repository.ipb.ac.id/handle/123456789/ 21928 diakses tanggal 5 April 2017 pukul $21.30 \mathrm{wib}$

Nasrun, N. 2009. Optimalisasi Produksi Nata De Coco Mentah Pada PD Risna Sari Kabupaten Cianjur Provinsi Jawa Barat. Skripsi. Fakultas Ekonomi dan Manajemen Institut Pertanian Bogor.

Bogor http://repository.ipb.ac.id/handle/123456789/ 21928 diakses tanggal 21April 2017 pukul 14.24 wib.

Pahan,I. 2006. Panduan Lengkap Kelapa Sawit. Penebar Swadaya. Bogor

Rizka, S. 1993. Kelapa Sawit Upaya Peningkatan Produktivitas. Kanisius. Yogyakarta
Setyamidjaja, D. 2006. Kelapa Sawit (Teknik BudiDaya, Panen, dan Pengolahan). Kanisius. Yogyakarta

Sinurat, I. F. 2003 Optimasi Produksi Hasil Olahan Kelapa Sawit Di Pabrik Pengolahan Kelapa Sawit Bah Jambi PT. Perkebunan Nusantara IV. Skripsi. Fakultas Pertanian Institut Pertanian Bogor. Bogor http://repository.ipb.ac.id/handle/123456789/ 19130 diakses tanggal 15 April 2017 pukul 18.50

Sunarko. 2007. Petunjuk Praktis Budidaya dan Pengolahan Kelapa Sawit. Agromedia Pustaka. Jakarta

Taha, H. A. 1996. Riset Operasi Suatu Pengantar. Binarupa Aksara. Jakarta 
